\title{
The Fulfillment of Infrastructure in Determining the Quality of Education in Purwakarta District
}

\author{
Johny Heriyanto Utomo*, Asep Sudarsyah \\ Educational Administration Department, School of Postgraduate Studies \\ Universitas Pendidikan Indonesia \\ Bandung, Indonesia \\ *johnyhucie@yahoo.co.id
}

\begin{abstract}
Aims of this research to determine the quality of education through the fulfillment of infrastructure in Purwakarta District. The research method used is a qualitative method through a case study in Purwakarta. The technique of collecting data through interviews, observation and documentation study. Data analysis techniques through the stages of data collection, data reduction, data presentation, verification and confirmation of conclusions. Checking and data validity using triangulation methods. The results showed that implemented under one roof to facilitate students especially in rural areas. However, the obstacles are uneven teaching staff and absorption the budget is too focused on output education. Therefore, the fulfilment of infrastructure is very urgent.
\end{abstract}

\section{Keywords-educational infrastructure, quality of education}

\section{INTRODUCTION}

Law of the Republic of Indonesia Number 20 of 2003 concerning the National Education System, states that education is a conscious and planned effort to create an atmosphere of learning and the learning process so that students actively develop their potential to have religious spiritual strength, self-control, personality, intelligence, noble morals, as well as the skills needed by him, society, nation and country. The law above shows that education is a vehicle that functions to create quality human resources (HR), namely graduates (output) who have the knowledge, skills and expertise in accordance with the demands of the development of science and technology.

In order to improve the quality of national education, educate the life of the nation, shape the character and civilization of the nation with dignity, the government has set National Education Standards as a reference for the implementation of education in Indonesia. National Education Standards are the minimum criteria for the education system in the Republic of Indonesia. Government Regulation Number 19 of 2005 which was refined through Government Regulation Number 32 of 2013 concerning National Education Standards, includes 8 standards, namely: content standards, process standards, graduate competency standards, standards for educators and educational personnel, standards of facilities and infrastructure, management standards, standards financing, and education assessment standards.

However, the problem of education in Indonesia, at a macro level, was conveyed by the Ministry of National Education, including that the quality of education of some schools is still low, especially primary and secondary schools in rural areas, such as in the interior and on the border.

The Ministry of National Education suggests several factors causing the gap in the quality of national education, including the partial application of the systems approach. School as a system should consist of context, input, process, output, and outcome. However, the facts in the field show that school development often focuses only on educational inputs such as students, teachers, infrastructure, and so on. Focus only on the educational process, such as the teaching and learning process, assessment of learning outcomes, school leadership, and so on. Focus only on output, such as national exam scores, scientific paper competitions, and so on. In fact, the school administration as a system must be carried out in its entirety, not partially. Education should be a system that includes various components of education, namely components of context, input, process, output, and outcome.

General policies in education issued by the local government of Purwakarta Regency include the compulsory nine-year basic education program. However, an evaluation of the absorption of the Purwakarta Regency budget shows that the budget is used only to focus on activities to achieve educational outputs, such as examinations and grades or graduation, while the need for facilities and infrastructure has received less attention.

According to Mulyasa [1] infrastructure is often seen as the cause of the low quality of education in schools. Therefore, the problem of fulfilling education infrastructure and quality of education in Purwakarta Regency will be the focus of this research.

According to Permendiknas General Provisions no. 24 of 2007, facilities are portable learning equipment, while infrastructure is basic facilities for carrying out school / madrasah functions. Educational facilities include buildings, 
classrooms, tables, chairs and learning media tools. Meanwhile, infrastructure includes, for example, yards, parks, fields, roads leading to schools and others. However, if it is used directly for the teaching and learning process, then this component is called an educational facility.

Kristiawan [2] argues that facilities are all facilities needed in the teaching and learning process, both mobile and immobile so that the achievement of educational goals and runs smoothly, orderly, effectively and efficiently. Meanwhile, infrastructure is all basic equipment or indirect facilities. support the course of the educational or teaching process such as school yards, parks and gardens. The above infrastructure needs to be managed in a professional manner in accordance with predetermined educational goals.

Educational facilities and infrastructure put forward by Permendiknas and Kristiawan [2] require good management. Education providers regulate and maintain educational facilities and infrastructure so that they can contribute optimally to the educational process and improve the quality of education. According to Baharudin [3] management of facilities and infrastructure is an activity of how to organize and manage educational facilities and infrastructure effectively and efficiently in order to achieve predetermined goals. Infrastructure management activities include planning, procurement, supervision, inventory and elimination activities.

The management of facilities and infrastructure is expected to be able to create pleasant conditions for both teachers and students to be in a clean, tidy and beautiful school. The availability of learning tools or facilities that are adequate quantitatively, qualitatively and relevant to needs and can be used optimally for the benefit of the education and teaching process, both by teachers and students.

According to Mulyasa [1], the theory that underlies the fulfillment of infrastructure must meet the following requirements:

- Planning for the fulfillment of school education facilities and infrastructure must be seen as an integral part of efforts to improve the quality of the teaching and learning process.

- Planning must be clear.

- Based on agreements and joint decisions with the parties involved in planning.

- Follow the guidelines (standards) of type, quantity and quality according to the priority scale.

- Procurement planning is in accordance with the provided budget ceiling.

- Follow the applicable procedures.

- Include parent elements.

- Flexible and can adapt to circumstances, changing situations and conditions that are not unexpected.
- Can be based on short term (1 year), medium term (4-5 years), long term (10 - 15 years).

Barnawi [4] describes the fulfillment of infrastructure as figure 1 follows:

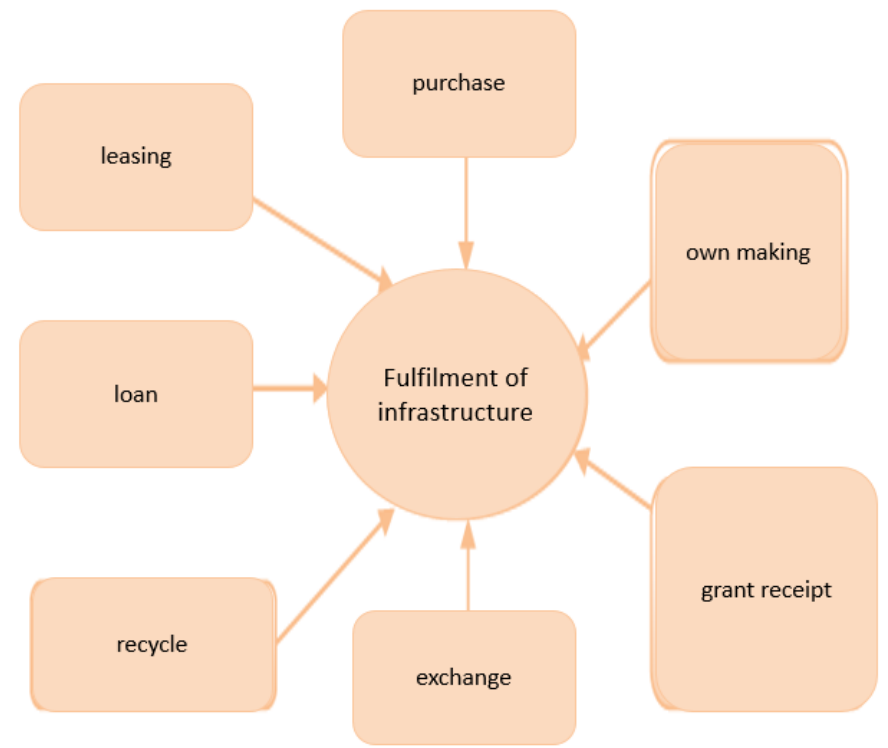

Fig. 1. Technical infrastructure fulfillment

According to Kristiawan [2], school quality management is an effort made in improving the quality of an educational institution in order to achieve educational goals. Quality in the context of education includes educational inputs, processes and outputs. The objectives of the quality of education are described as figure 2 follows:

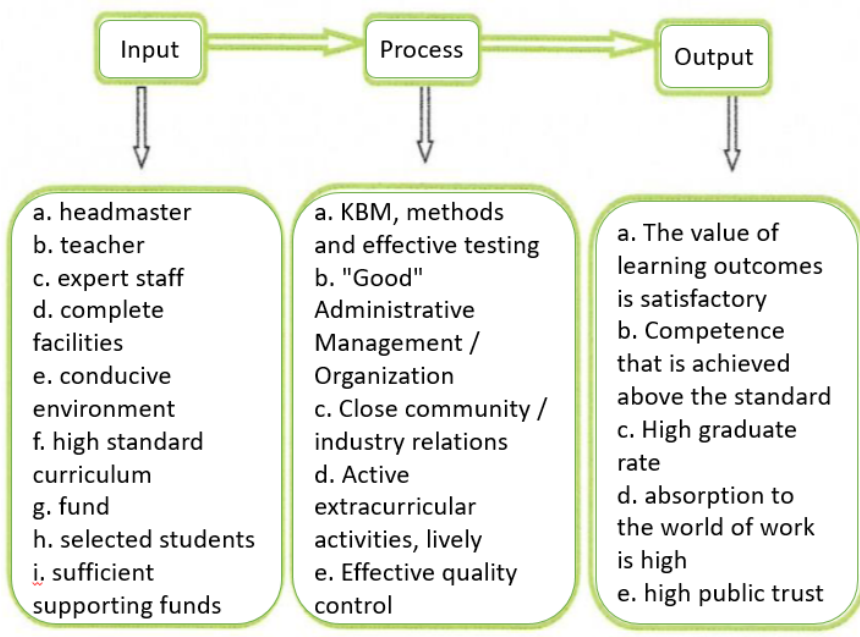

Fig. 2. Education quality goals

Mulyasa [1] argues that there are at least three main requirements that must be considered in education development in order to contribute to improving the quality of human resources (HR), namely building facilities, quality books and professional teachers and educational staff. 


\section{MethodS}

This research is a qualitative study using a program evaluation approach, namely activities that aim to measure program success and play a role in facilitating rational and objective decision making. This program evaluation approach is managerial oriented so that the evaluation model used is Context, Input, Process, and Product (CIPP) formulated by Stufflebeam et al. CIPP is a process of determining, collecting and providing information required for alternative decisionmaking [5].

Data collection techniques using observation, interviews and documentation. Data analysis using descriptive analysis techniques through the stages of data reduction, data display, and drawing conclusions. Miles and Huberman stated that activities in data analysis are data reduction, display data, and conclusion drawing / verification. Checking and data validity using triangulation. According to Moleong [6], triangulation can be done using different techniques, namely interviews, observation and documents. This triangulation is not only used to check the correctness of the data but also to enrich the data. Triangulation can also be useful for investigating the validity of the researchers' interpretation of the data, because triangulation is reflective.

\section{RESULTS AND DISCUSSION}

Evaluation of the 9-year must-learning program in Purwakarta Regency includes program planning, program implementation process and program implementation results/impacts, consistent with what Arikunto [7] said, one form of program assessment is CIPP. CIPP stands for Context Evaluation, Input Evaluation, Process Evaluation, Product Evaluation. The evaluation of this program is the basis for the fulfillment of educational infrastructure in Purwakarta Regency.

Based on the research findings, the implementation of the 9-year compulsory education policy is carried out under one roof, namely the use of SD and SMP education facilities located in one location, especially in villages that are difficult to reach by public transportation.

Context evaluation is an attempt to describe and detail the environment, unmet infrastructure needs, population and sample served, and project objectives. This context also helps plan decisions, determine needs, to be achieved by the program, and formulate program objectives. The context in this study is the evaluation of the context in the implementation of the policy to fulfill the educational infrastructure in the 9-year compulsory education program.

General policies in the education sector issued by the local government of Purwakarta Regency consist of a nine-year compulsory basic education program, a one-stop integrated SD-SMP education policy and a free education policy. This policy needs to be supported by adequate facilities and infrastructure. However, the Purwakarta Regency government implements a one-stop integrated SD-SMP education policy, where the SD-SMP school building is established in the same location, especially in areas with minimal public transportation such as in rural areas so that students after graduating from SD can continue to SMP in the same location without having to pay for fees because the location of the secondary school is far from the domicile of where he lives.

The nine-year compulsory education policy is supported by a free education policy intended for SD and SMP students using BOS funds whose budget allocations come from the central government $\mathrm{APBN}$ and the regional government APBD.

The obstacles to the 9-year compulsory education policy in Purwakarta Regency include the uneven distribution of the teaching staff. The number of qualified teaching staff is more concentrated in urban areas, while in rural areas the number is still very minimal. Another obstacle is the lack of public understanding of education and education policies.

Another obstacle is the absorption of the Purwakarta Regency budget, which shows that the budget is used only to focus on activities to achieve educational output, such as examinations and grades or graduation, while the need for facilities and infrastructure is still not getting enough attention.

\section{CONCLUSION}

The education policy in Purwakarta Regency, which is a 9year compulsory education which applies under one roof, requires adequate infrastructure. Therefore, the fulfillment of educational infrastructure is very urgent.

\section{ACKNOWLEDGMENTS}

The one-stop policy in implementing the 9 year compulsory education will be effective in improving the quality of education if it is supported by educational facilities and infrastructure that are in accordance with the needs.

\section{REFERENCES}

[1] E. Mulyasa, Menjadi Guru Profesion-al, Menciptakan Pembelajaran Kreatif dan Menyenangkan. Bandung: Rosda Karya, 2013.

[2] M. Kristiawan, Manajemen Pendidikan. Yogyakarta: Deepublish, 2017.

[3] H. Baharudinn and Zamroni, Ma-najemen Mutu Pendidikan. Tulung Agung: Akademia Pustaka, 2018.

[4] A. Barnawi, Manajemen Sarana dan Prasarana Sekolah. Yogyakarta: AR-Ruz Media, 2014

[5] R. Ananda and T. Rafida, Pengantar Evaluasi Program Pendidikan. Medan: Perdana Publishing, 2017.

[6] L.J. Moleong, Metode Penelitian Kualitatif, Bandung: PT Remaja Rosdakarya, 2010.

[7] S. Arikunto, Prosedur Penelitian Suatu Pendekatan Praktik. Bandung: Rineka Cipta, 2012 